\title{
VOCABULARY SKILLS DEVELOPMENT AMONG STUDENTS: AN ETHNOGRAPHY
}

\author{
Charito G. Ong, Elva S. Maramara, Sophomore T. Vacalares and K Marie D. Zambas \\ University of Science and Technology of Southern Philippines, Philippines
}

\begin{abstract}
This study is on the development of English vocabulary skills of selected High School and College students of Bukidnon and Cagayan De Oro City. Specifically, it sought to focus on four areas: when teachers develop vocabulary, the teaching techniques employed to develop vocabulary, students' reaction to the activities presented and the behaviors displayed by students to show understanding of new words introduced.

An ethnographic approach to classroom observation was used in this study. The descriptive method served as means to analyze and interpret the gathered data on vocabulary development. The data were gathered through the use of cassette recorder and video tape. Actual observation was also conducted by the researchers to the sample classes. Moskowitz' (2006) behavior categories for language students aided the researchers in describing students' reactions to vocabulary activities presented. A total of four hours was allotted for the gathering of data, equivalent to six lessons. Of the six lessons observed, two were tape recorded and four were video-taped.

Findings revealed that the development of vocabulary skills was generally done at the beginning of the lesson. There were only few instances in which it was done at the middle of the discussion. Vocabulary was unlocked through the use of context clues varying from semantic definition, explanation, description and appositive clues. Students enjoyed guessing the words' meaning when used in context that choral responses were prevalent. They manifested that they understood the meaning of the new words developed by using the words in exact context during the lesson activities.
\end{abstract}

\section{KEYWORDS}

Vocabulary Development, Ethnography, English Classes

\section{INTRODUCTION}

There is much agreement among linguists and language experts that inadequate vocabulary development is the basis for many problems associated with underachievement. Vocabulary deficiencies are associated with difficulty in comprehending sentences, depressed IQ test performance, and inefficient reading speed. After students leave school, inadequate vocabulary development continues to affect vocational success adversely (Otto, 2008). Vocabulary development then is an essential skill, which needs emphasis in all English classes.

Yet it is a reality that quite a number of students still belong to the underachiever's category as manifested by their failing marks. The question may be posed "how far have the English teachers gone to provide adequate vocabulary development in their English classes?" Mangiere (2002) posits that despite the obvious importance of vocabulary in the reading process, it is frequently underemphasized by teachers in their classrooms. He further states that it is also a facet of reading about which some teachers have many misconceptions. Therefore, there is a need to find out what is really going on in English classes (Willmott, 2002).

However, knowledge of what actually goes on in the classrooms is extremely limited. In his book on ethnographic approaches to the classroom, Van Lier (2008) justifies that ethnography is relevant and valuable in increasing one's knowledge of classrooms which can only be done by going into classrooms for data gathering. Nunan (2005) also says that there is no substitute for direct observation as a way of finding out about language classrooms. Certainly, if researchers want to enrich their understanding of language learning and teaching, they need to spend time looking in classrooms (Comaroff, 2003). The classroom is where the action is, the place to look for ways to record and investigate action. 
Therefore, providing an ethnographic description of the development of vocabulary skills of High school and College English students is deemed necessary. Vocabulary is a necessity in the development of one's speaking, reading, listening and writing skills.

\section{METHODOLOGY}

The ethnographic approach to classroom observation was used in conducting this study. This is an open-ended approach wherein the observers first identified areas of concern and devises what kind of data might seem appropriate as cited by Wallace (2001). Wajnryb (2002) further states that in doing an ethnographic record of the lesson, the researcher notes down chronologically the main events in the lesson and their impact. Events need to be brief and synoptic to keep records in real time. Hence, in this paper, actual classroom lessons in English classes were observed and verbal interactions were tape-recorded and video-taped. These were then transcribed, interpreted and analyzed based on the questions stated towards vocabulary development.

\section{RESULTS AND DISCUSSIONS}

The total of four hours tape-recorded, video-taped and actually observed English classes revealed that most of the vocabulary words introduced were developed at the beginning of the lesson. It was observed that words such as resonance, wick, intermittent, accolade, sonorous, awry and grumpy were unlocked at the start of the lesson. These words were discussed at the immediate start of the lesson, before the lesson activities were done. Only two words were unlocked at the middle of the discussion. They were: accolade and wick. These words were developed before the activities were done. Excerpts of the lessons from the two sections support these.

Furthermore, the excerpt shows that all vocabulary words introduced were developed at the beginning of the lesson. Five vocabulary words were introduced as follows: resonance, accolade, sonorous, grumpy, and intermittent. Another excerpt taken from the high school, a double period class; revealed three vocabulary words developed in the session. One of these three words was introduced at the middle of the discussion, before the students made an application letter for an activity. The word was accolade. The rest of the words, which are intermittent and grumpy were developed at the beginning of the lesson.

From the college classes, six vocabulary words were developed. Five of these were developed at the beginning of the lesson. They were: awry, askance, impoverish, gird and succulent. The only word developed at the middle of the lesson was the word wanton. An excerpt supports this.

During the second meeting of the high school classes, only one word was introduced, the word whim. This word was developed at the beginning of the lesson. This is also supported by an excerpt. Another excerpt shows two vocabulary words being developed at the beginning of the lesson. These are incredulous and glean.

Excerpts 1, 2, 3, 4 and 5 show that most vocabulary words were unlocked at the start of the lesson, before the lesson activities were tackled by the class. The teacher made the students understand the words meaning before they were used in the activities of filling out an application letter, expressing ability and interest, expressing a wish, having a job interview writing an application letter. The unlocking of words before they were used in succeeding activities facilitated more student interaction. The use of these words, unlocked beforehand, enabled the students to cope with the teachers' activities. There were two vocabulary words unlocked at the middle of the discussion. These were accrued and whim.

The excerpts show that words like resonance, intermittent, grumpy, whim and accolade were unlocked as a review for the past lesson. The re-unlocking of the said words was done at the immediate start of the lesson. Some words such as accolade and wanton were re-unlocked at the middle of the discussion. After these, other words were unlocked also. These were: sonorous and accrued which were then used for the succeeding activities. The word incredulous was used by the students to fill out an application form while glean and intermittent in were used in making sentences to express ability and interest.

As a summary, the table that follows answers when teachers develop vocabulary. 
Table 1. When do Teachers Develop Vocabulary?

\begin{tabular}{|c|c|c|}
\hline Classes & Words developed & When was it developed \\
\hline College & $\begin{array}{ll}\text { 1. } & \text { Resonance } \\
\text { 2. } & \text { Wick } \\
\text { 3. } & \text { Intermittent } \\
\text { 4. } & \text { Accolade } \\
\text { 5. } & \text { Sonorous }\end{array}$ & Beginning of the lesson \\
\hline High School & $\begin{array}{ll}\text { 1. } & \text { Whim } \\
\text { 2. } & \text { Incredulous } \\
\text { 3. } & \text { Glean } \\
\end{array}$ & $\begin{array}{l}\text { Beginning of the lesson } \\
\text { Middle of the lesson }\end{array}$ \\
\hline College & $\begin{array}{ll}\text { 1. } & \text { Resonance } \\
\text { 2. } & \text { Wick } \\
\text { 3. } & \text { Intermittent } \\
\text { 4. } & \text { Accolade } \\
\text { 5. } & \text { Sonorous }\end{array}$ & $\begin{array}{l}\text { Beginning of the lesson } \\
\text { Middle of the lesson }\end{array}$ \\
\hline High School & 1. Whim & Beginning of the lesson \\
\hline High School & $\begin{array}{l}\text { 1. Incredulous } \\
\text { 2. Glean }\end{array}$ & Beginning of the lesson \\
\hline
\end{tabular}

Transcriptions show that vocabulary was developed through the use of context clues. All words were unlocked through the use of context. Excerpts one to five support this claim. Context clues are the kinds of aid that pupils often encounter. Evident from these excerpts are aids like sentences used by the teacher to arrive at word meanings. Semantic definitions and descriptions were the usual kinds of aid given. This is true from excerpt one to six. Not only sentences were used as clues, words were written on the board as answer clues or choices. After the teacher said the sentence clues twice, students chose the meanings from the list on the board. This facilitated gathering of immediate responses from the students.

The teacher developed vocabulary ion both sections with the use of semantic clues. Clues given were derived from the meanings of the words co-occurring with the unknown words. Various kinds of semantic clues were utilized by the teacher to arrive at the meaning of the words unlocked in class.

Table 2. Techniques used by the Teacher in Developing Students' Vocabulary

\begin{tabular}{|c|c|c|}
\hline Classes & Words developed & Technique Used \\
\hline College & $\begin{array}{ll}\text { 6. } & \text { Resonance } \\
\text { 7. } & \text { Wick } \\
\text { 8. } & \text { Intermittent } \\
\text { 9. } & \text { Accolade } \\
\text { 10. } & \text { Sonorous } \\
\end{array}$ & $\begin{array}{l}\text { Context by definition } \\
\text { Semantic Appositive } \\
\text { Semantic Definition } \\
\text { Semantic Appositive } \\
\text { Semantic Appositive }\end{array}$ \\
\hline High School & $\begin{array}{ll}\text { 4. } & \text { Whim } \\
\text { 5. } & \text { Incredulous } \\
\text { 6. } & \text { Glean } \\
\end{array}$ & $\begin{array}{l}\text { Semantic Appositive } \\
\text { Semantic Appositive } \\
\text { Definition made by students }\end{array}$ \\
\hline College & $\begin{array}{ll}\text { 6. } & \text { Resonance } \\
\text { 7. } & \text { Wick } \\
\text { 8. } & \text { Intermittent } \\
\text { 9. } & \text { Accolade } \\
\text { 10. } & \text { Sonorous }\end{array}$ & $\begin{array}{l}\text { Semantic Appositive } \\
\text { Semantic Definition } \\
\text { Semantic Appositive } \\
\text { Semantic Appositive } \\
\text { Semantic Definition } \\
\text { Semantic definition }\end{array}$ \\
\hline High School & 2. Whim & Semantic Explanation \\
\hline High School & $\begin{array}{l}\text { 3. Incredulous } \\
\text { 4. Glean }\end{array}$ & $\begin{array}{l}\text { Semantic definition } \\
\text { Semantic definition }\end{array}$ \\
\hline
\end{tabular}


The four -hour video-taped and tape recorded data in both college and high school English classes yielded various reactions shown by the students to the activities presented by the teacher for vocabulary development. Most reactions were similar and patterned after the scheme devised by Moskowitz (2006) for documenting classroom behavior of language students. These are summarized on the next table.

Table 3. Students' Reactions towards Vocabulary Development

\begin{tabular}{|c|c|}
\hline Activities Presented by the Teacher & Students' Reactions \\
\hline Completing an Application letter & $\begin{array}{l}\text { Looked blankly at the teacher, made unnecessary } \\
\text { noise, repeated what the teacher said, talked using } \\
\text { their native language, repeated the word unlocked, } \\
\text { choral responses, smiled at the video camera, teased } \\
\text { the one reciting, laughed and giggled, corrected the } \\
\text { teacher's use of did and do }\end{array}$ \\
\hline Completing a Bio-data & $\begin{array}{l}\text { Repeated the teacher's words, laughed at the word } \\
\text { used, voiced out their want to call the sample, talked } \\
\text { using their native language, added funny words to } \\
\text { what the teacher read, choral responses, made fun of } \\
\text { answers, forced classmates to stand, repeated } \\
\text { classmates' answers }\end{array}$ \\
\hline Expressing ability & $\begin{array}{l}\text { Gave direct answers, created noise, answered without } \\
\text { being called, gave inaudible replies, laughed at their } \\
\text { classmates' responses and interest }\end{array}$ \\
\hline Expressing a wish & $\begin{array}{l}\text { Laughed and teased their classmates' answers, } \\
\text { shouted and laughed at the camera, scratched the } \\
\text { head due to confusion, kept on looking at the watch, } \\
\text { asked seatmate, drummed on the chair, did not listen } \\
\text { to the instruction }\end{array}$ \\
\hline Making up an interview & $\begin{array}{l}\text { Worked seriously, made minimal noise, laughed } \\
\text { while talking, did not face the camera, covered the } \\
\text { face while reciting, was shy to face the camera }\end{array}$ \\
\hline Making an application letter & $\begin{array}{l}\text { Frowned, ignored the video camera, concentrated on } \\
\text { their work, was hesitant to go to the front, smiled at } \\
\text { the video camera }\end{array}$ \\
\hline Unlocking of Difficulties & $\begin{array}{l}\text { Silent, choral responses, answered with a smile, gave } \\
\text { appropriate responses easily, provided inaudible } \\
\text { replies, winked, scanned notes, touched the hair } \\
\text { repeatedly, repeated classmates' answers, played } \\
\text { with ball pen, whispered to confirm an answer, } \\
\text { listened attentively }\end{array}$ \\
\hline Filling out an application letter & $\begin{array}{l}\text { Took notes of what was heard, meditated, talked } \\
\text { softly with people behind them, choral responses, } \\
\text { smiled at the video camera }\end{array}$ \\
\hline Expressing ability and interest & Recited softly, teased their classmates, laughed \\
\hline Expressing wish & $\begin{array}{l}\text { Gave direct answers, teased, laughed, covered face, } \\
\text { listened attentively to the one reciting }\end{array}$ \\
\hline Application letter writing & $\begin{array}{l}\text { Worked attentively, covered the mouth, smiled, read } \\
\text { one's work seriously, laughed, gave inaudible } \\
\text { answers, did not listen to the one reciting in } \\
\text { preparation for his turn to recite }\end{array}$ \\
\hline
\end{tabular}




\section{FINDINGS}

The study came up with the following relevant findings:

Students from the third section of the high school level The development of vocabulary skills was generally done at the start of the lesson. This was observed from both high school and college classes. The teacher did this since the words unlocked were used to further students' understanding of the succeeding activities. The vocabulary words introduced were used in the lesson activities they did. Unlocking terms before the lesson activities were done, helped most students. The others obviously need no helping in understanding the terms unlocked for the words were too easy for their level. Also, the answer clues and the sentence patterns which were presented helped and led the students to participate actively in the recitation.

Some words were unlocked in the middle of the lesson. This was done before the succeeding activities were tackled.

Vocabulary was unlocked through the use of context clues. Sentences were provided by the teacher to serve as guide to come up with the words' meaning. Most words were semantically defined since the teacher made use of clues derived from the meaning of the words co-occurring with the unknown words. Definition, explanation, and description of the words unlocked were the clues provided for the sentences. Choices were also written on the board which helped the students give answers. The same techniques were used for both sections.

Varied reactions were manifested by students at the time of the unlocking of difficulties and during the presentation of activities for vocabulary development. The students' behavior included specific responses and immediate replies. Some responses were choral and use of the mother language was predominant, only a few non-verbal gestures or facial reactions were seen such as scanning of notes, looking at the camera and blankly looking at the teacher. Only for a few words were students observed to be frowning showing confusion about what they were doing. Generally, students from these classes were attentive during the presentation of activities for vocabulary development.

Students from the third section of the high school level had such a hard time answering the vocabulary reviewed without the context. This was due to their lack of attention to listen to the clues given. Most students responded using their background knowledge coupled by the rendition of choral responses. Silence was only prevalent after the reading of the context. Confusion also occurred among the boys who were not behaving as the teacher wished. Most used the native language in talking and delivering their answers and laughter was dominant as a sign of mockery after a student recited. They laughed every time the video camera was focused on somebody in the room. Non verbal reactions were also observed: frowning, smiles, blank reactions, and unnecessary movements. Most students from this section were inattentive.

These observations are based from the modified pattern of Moskowitz' (2006) behavior categories of language students. Generally, students displayed positive attitude towards vocabulary development. They were able to use the words they learned during the making of the application letter. Words like sonorous, intermittent, awry and grumpy at were utilized in the making of the application letter. Most of them were able to come up with sentences during the recitation with the use of the vocabulary words introduced like gird, whim, and accolade. Words unlocked at the start of the lesson were also successfully used when they were asked to have an information transfer activity that is to fill in the blanks in the application letter and during the making of an interview. The word sonorous, and succulent to fill in the blanks in the application letter. During the interview, the same words were also used.

\section{CONCLUSIONS}

The following conclusions were drawn based from the findings of the study:

The development of vocabulary skills should be done in any part of the lesson whenever necessary. Words which will be introduced should be truly new words, not those that are already part of the students' vocabulary. 
The teaching technique employed towards vocabulary development was limited to one technique. This was the use of context clues. Varied teaching techniques should have been utilized for more student participation during the unlocking of terms which would cater for more vocabulary retention. Though the vocabulary words presented were not really difficult, students had quite a hard time recalling the word-meaning discussed from the previous session. The vocabulary words which were introduced should have been more difficult, something new and challenging to stimulate students' thinking and to expand vocabulary and to promote communication.

Unlocking of words through context is of no question especially in eliciting responses from the students. Most students enjoy guessing a word's meaning especially if a context is provided. For this reason, students from both high school and college levels were able to arrive at the exact meaning of the words unlocked. Yet, students should have been given more chances of working out meanings for themselves. The words' meaning should not have been provided on the board to serve as choices. Letting students discover meanings for themselves will make them more independent in defining the meanings of words rather than depending too much on context. This led them to have lesser vocabulary retention although the vocabulary words introduced were too easy.

Students' negative reaction manifested by teasing and mockery towards their classmates who are reciting deeply affected the others. This could hinder vocabulary growth. Patterns were provided on the board for students to come up with desired sentences. Words introduced were too easy. Students obviously found the activities too easy also. Not much vocabulary development was shown by the students. The activities provided were not that meaningful enough to promote vocabulary retention for the researcher to know that vocabulary development was going on. Students were not much involved for a sporadic giving of sentences were done by them. Patterns were on the board. All they had to do was choose to come up with sentences by choosing from the patterns. Spontaneous ideas did not emerge from them for they were always provided with patterns to follow and choices to choose from. The teacher should have given more activities to ensure vocabulary retention through application, such as contexts for using the new words. Vocabulary development was usually done at the start of the lesson. Discovery and contextual clues were utilized as techniques by the teacher in introducing new words. There was vocabulary development during the information transfer activity and the making of an application letter. Words that the students learned were used in the said activities appropriately. There were only two instances in which vocabulary was developed at the middle of the discussion.

\section{RECOMMENDATIONS}

From the written results of the student in the findings and conclusions, the following concepts are recommended.

Development of vocabulary skills should not only be done at the start of the lesson. It should be done whenever there is a need for the benefit of the students.

Words which are initially acquired by the students can possibly be forgotten if not adequately reinforced. This was observed in both secondary and tertiary levels. During the lesson reviews, students showed that the vocabularies they already knew previously were not retained. Hence, teachers must be very careful in choosing suitable techniques that would really ensure definite vocabulary growth and retention. After all, the teachers are not only after the number of words acquired but the competence to use the words functionally. Acquiring new words would mean trivial if not fully understood and retained.

A seminar-workshop on teaching techniques towards vocabulary development must be offered to English teachers. This will help them realize that there is a need to present meaningful; activities for vocabulary development. Teachers must be reoriented on the current trend to develop vocabulary skills of students. They must adapt a communicative way of developing students' vocabulary skill. The activities they should present must be meaningful and really involve the students to facilitate vocabulary development and retention. 


\section{REFERENCES}

Comaroff, J., \& Comaroff, J. (2003). Ethnography on an awkward scale: Postcolonial anthropology and the violence of abstraction. Ethnography, 4(2), 147-179.Creativity Research Journal, 19(2/3), pp 213-225.

Mangiere, John (2002). Elementary Reading. New York. Mc Graw Hill Inc.

Moskowitz, G. (1976). The Classroom Interaction of Outstanding Foreign Language Teachers. Foreign language annals, 9(2), 135-143.

Nunan, David (2009). Understanding Language Classrooms. Great Britain. Prentice Hall International.

Otto, Nicholas. (2008). Communicating Effectively. New York. Longman Inc.

Van Lier Penny. (2004). Teaching Listening Comprehension. Great Britain. Cambridge University Press.

Wallace, Wayne (2000). Corrective and Remedial Teaching. U.S.A. Houghton Mifflin Co.

Wajnryb, Ruth. (2002)The Development of Language and Literacy in Young Children. New York. Mc Graw Hill Inc.

Willmott, H. (Ed.). (2002). Critical management studies. Sage. 